\title{
SASTRA AL-QUR'AN DI TENGAH ALIRAN SASTRA INDONESIA
}

\author{
Helmi Syaifuddin
}

Dosen Jurusan Bahasa dan Sastra Arab,

Fakultas Humaniora dan Budaya, Universitas Islam Negeri (UIN) Malang.

Jalan Gajayana No. 50 Telepon (0341) 551354, Faksimile (0341) 572533 Malang 65144.

\begin{abstract}
Throughout Indonesia's long history, the meaning of Indonesian art has been the subject of debate. Is just "art for arts sake", or is there a more obscure socio-political message behind the more obvious depictions. In socio-political context it would seem that Indonesian art expresses socio-political themes, but in examples depicting surrealism, absurdity, existentialsm, prophetic art and post-modernist etc. Indonesia's art is nor a modern phenomenon. Indonesia's art seems to continually focus on the more superficial; ideas without attempting to make even minor changes to past cultural influence. In this context therefore the emergence of a new paradigm is not surprising, and the emergence of a Koranic influence in Indonesian art is becoming the latest paradigm in interpreting the reality and meaning of contemporary indonesian art.
\end{abstract}

Key words

Throughout Indonesia's, Al-Qur'an's literary, Art 


\section{Pendahuluan}

Memasuki era milenium baru, masyarakat digelisahkan oleh harapan dan upaya untuk menghadirkan sesuatu yang baru dalam kehidupan mereka. Manifestasi paling nyata adalah tuntutan reformasi yang kuat dalam berbagai aspek kehidupan bermasyarakat dan bernegara. Pemicu munculnya kegelisahan tersebut adalah rasa tidak puas terhadap apa yang telah lampau ataupun yang sedang berlangsung.

Wacana pergantian abad seringkali dikaitkan dengan kemungkinan pergantian peradaban manusia. Apa yang dimaksud dengan milenium baru dikaitkan dengan munculnya gagasan mengenai era baru dan teknologi baru. Memasuki milenium baru, dalam masyarakat seakan terbentuk structure of feeling yang cukup tersebar dan terbagi di berbagai lapisannya. Untuk masyarakat kesenian, termasuk kesusastraan, kegelisahan muncul dalam bentuk ikhtiar untuk menemukan paradigma baru dalam cara pemahaman dan praktik seni. (Farouk, 2001:1-3).

Tulisan ini akan mencoba menjawab persoalan upaya menemukan paradigma kesenian tersebut dengan memusatkan perhatian pada cara pemahaman dan praktik sastra al-Qur'an. Sengaja di sini tidak digunakan istilah sastra Islam, sastra Islami, sastra profetik, sastra dakwah, sastra pesantren, atau pun sastra religi karena istilahistilah tersebut terkadang terdengar asing bagi telinga awam. Harap dimaklumi pula bahwa membangun paradigma bersastra yang dibutuhkan di masa depan adalah aktivitas yang tidak lain kecuali konstruktif. Dengan demikian, orang tidak akan dapat melepaskan diri dari cengkeraman subjektivitas dan kekiniannya sendiri. Karena itu, jika tulisan ini tetap melakukannya, maka hasil yang dibuahkan tidak lebih dari sekedar tawaran terbuka yang siap untuk diubah dan bahkan ditiadakan.

\section{Problem Paradigmatik Sastra Indonesia}


Menemukan paradigma seni atau pun sastra diakui memang akan menghadapi banyak kendala mengingat realitas kesenian atau kesastraan yang telah dan sedang berlangsung pada dasarnya beraneka ragam dan terbuka bagi banyak kemungkinan interpretasi (multi-interpretable). Kendala utama terletak pada penentuan karya atau paham mana di antara berbagai karya dan paham tersebut dapat dianggap paradigmatik.

Selain itu, gagasan mengenai paradigma baru akan menjadi jelas dan terarah apabila telah diperoleh gagasan yang pasti mengenai paradigma lama yang akan ditinggalkan. Dengan kata lain, menyusun paradigma baru dengan sendirinya menuntut usaha membangun paradigma lama terlebih dahulu. Bersamaan dengan itu, mengingat keragaman sastra dan sifatnya yang multi interpretasi, maka identifikasi tertentu terhadap kemungkinan paradigmatik dari sastra lama tidak boleh menutup peluang bagi kemungkinan identifikasi yang lain.

Pada dasarnya, sebuah paradigma terbentuk jika ada kesepakatan pada komunitas tertentu mengenai berbagai pemikiran yang dianggap normal. Dalam ilmu pengetahuan, kesepakatan itu biasanya dimulai dengan munculnya sebuah penemuan, yang selanjutnya dijadikan dasar bagi segala pemikiran dan praktik ilmu pengetahuan. Terbentuknya kesepakatan mengenai hal yang normal akan diikuti pula oleh kesepakatan mengenai sesuatu yang abnormal. Pemikiran abnormal dimaksud sebgai segala pemikiran dan praktik yang berada di luar bingkai paradigma yang disepakati. Kecenderungan yang demikian mengimplikasikan bahwa dalam rentang sejarah tertentu tidak hanya satu bentuk pemikiran dan praktik yang hidup, yang dianggap paradigmatik sebagaimana dimaksudkan, tetapi terdapat pula berbagai bentuk pemikiran dan praktik lain yang ada di luarnya. Dalam teori wacana, hal terakhir biasa disebut sebagai subteks. (Farouk, 2001:7).

Kasus sastra Indonesia berikut adalah cermin dari praktik kesepakatan mengenai sebuah paradigma, tetapi masih memberi ruang bagi pemikiran dan praktik sastra di luarnya. Konon, keragaman sastra 
Indonesia sudah ada sejak masa awal kelahirannya, sehingga penentuan karya sastra mana yang mewakili paradigma sastra Indonesia cukup mengalami kesulitan. Dalam sejarah disebutkan bahwa karya-karya sastra Balai Pustaka dibedakan dari karya-karya sastra yang lahir di luarnya, yang oleh Balai Pustaka disebut "Bacaan Liar". Di lingkungan Pujangga Baru, terjadi polemik yang cukup keras antara Sutan Takdir Alisjahbana dan Sanusi Pane. Pada dekade awal sesudah kemerdekaan, dari tahun 1940-an sampai tahun 1950-an, ditemukan beberapa paham. Dari dekade 1950-an hingga 1960-an setidaknya ditemukan dua gagasan yang bertentangan mengenai ciri-ciri sastra pada periode tersebut, yaitu antara gagasan Ajib Rosidi dan H.B. Jassin. Pada tahun 1970-an kecenderungan sastra seakan seragam, meski belum jelas dan muncul kesepakatan mengenai batas akhir dari kecenderungan tersebut. Ada pengakuan bahwa di tahun 1980-an telah muncul kecenderungan baru, misalnya sufisme, tetapi tidak sedikit pula yang tidak bersepakat dengan pandangan tersebut. Tahun-tahun terakhir dekade 1980-an hingga awal 1990-an, kancah pemikiran sastra dihiasi oleh gagasan mengenai sastra kontekstual, sastra pedalaman, dan postmodernisme (Farouk, 2001:4).

Harus diakui pula bahwa realitas sastra Indonesia, dalam sejarahnya, penuh dengan jargon dan perdebatan abstrak mengenai berbagai paham dan aliran, baik itu paham dan aliran sastra maupun politik dan sosial. Contoh kongkrit dari hal itu adalah ketika iklim politik Indonesia dikuasai oleh wacana revolusi, sastra Indonesia, seperti yang terekam dalam Surat Kepercayaan Gelanggang, ikut berbicara mengenai revolusi. Ketika iklim politik dikuasai oleh wacana sosialisme, sastra pun terseret untuk berbicara mengenainya. Begitu juga dalam hal surealisme, absurdisme, eksistensialisme, sastra profetik, sastra pedalaman, postmodernisme, dan sebagainya.

Tampaknya sastra Indonesia belum keluar dari kecenderungan pemujaan terhadap impuls-impuls gagasan abstrak yang berlangsung di permukaan dan tanpa pernah melakukan perubahan kultural yang mendasar. Meski demikian, kecenderungan tersebut sebaiknya tidak dianggap sebagai sesuatu yang fatal, tetapi dapat dipandang sebagai 
salah satu kekuatan kehidupan sastra Indonesia yang dapat dengan cepat menerima dan menyerap berbagai perubahan dalam lingkungan global.

\section{Sastra dan Agama}

Sastra-sastra Indonesia kebanyakan telah mengalami interaksi antara satu dan yang lain. Dalam interaksi tersebut biasa terjadi saling mengambil, yaitu unsur-unsur tertentu dalam satu sastra daerah digunakan dalam sastra daerah yang lain. Misalnya, beberapa sastra daerah telah mengalami kontak dengan sastra Jawa dan mengambil berbagai unsurnya. Sastra Sunda mengambil bentuk pupuh dan digunakan untuk mengubah cerita-cerita yang sudah tersedia dalam sastra Sunda menjadi wawacan, yang biasa dibawakan dengan cara ditembangkan. Dalam sastra Melayu terdapat cerita-cerita Panji yang berasal dari sastra Jawa (Rusyana, 2000:5).

Interaksi juga terjadi antara sastra Indonesia dengan gelombanggelombang agama dan budaya besar pada beberapa zaman seperti agama dan budaya Hindu, Islam, dan Kristen. Sehubungan dengan interaksi tersebut, dalam sastra Indonesia terdapat hasil-hasil sastra yang secara umum disebut sastra pengaruh Hindu, pengaruh Islam, dan pengaruh Kristen. Untuk dapat memilih dan menerima bahan-bahan yang berasal dari budaya dan agama itu dituntut adanya rujukan dan pertimbangan yang memadai. Salah satunya adalah adanya hubungan yang erat antara sastra dan agama, mengingat keduanya memiliki persamaan yang fundamental soal nilai-nilai perasaan yang luhur (eddy; 1983: 62). Oleh karena itu, seringkali sastra memilih nilai agama sebagai temanya dan agama memilih sastra sebagai media untuk menyampaikan ajarannya.

Seni yang lahir karena agama sudah mempunyai patokanpatokan yang jelas. Sesuai dengan ciri agama sebagai dogma, keindahan yang diperjuangkan oleh seni yang timbul dari agama juga bersifat normatif, seperti tampak dalam puisi para penyair agamawi. Semua itu 
wajar, karena seni di sini adalah sarana pengucapan manusia untuk bertaqwa (Darma, 1982: 1942).

Bagi agama Islam, patokan-patokan normatif sebagaimana yang dimaksudkan dapat dirujuk dalam al-Qur'an. Karena, al-Qur'an sebagai kitab suci agama Islam dimaksudkan untuk menjadi petunjuk, bukan saja bagi anggota masyarakat kitab suci ini diturunkan, tetapi juga bagi seluruh masyarakat manusia. Kitab tersebut memuat tema-tema yang mencakup seluruh aspek kehidupan manusia, seperti pola hubungan manusia dengan Tuhan, hubungan antarmanusia, dan hubungan manusia dengan lingkungan alam sekitarnya. Sebagai kitab suci yang menghadapi masyarakat dengan kebudayaan dan peradaban yang terus berkembang dan maju, di dalamnya terdapat ayat-ayat kealaman (sciences) dan kemasyarakatan. Ayat-ayat itu dijadikan pedoman, motivasi, dan etika dalam rekayasa masyarakat (social engineering) (Azra, 1999:128).

Rekayasa masyarakat adalah penciptaan tatanan kemasyarakatan yang sesuai dengan kondisi objektif setiap komunitas masyarakat yang tetap bersendi kepada prinsip-prinsip umum yang ditetapkan al-Qur'an. Substansi ajaran al-Qur'an tidak bermaksud menciptakan masyarakat seragam di seluruh belahan bumi dan di sepanjang sejarah, tetapi memberikan prinsip-prinsip umum yang memungkinkan terwujudnya pola keseimbangan hidup di dalam masyarakat tertentu.

Dari hasil penelitian para ilmuwan Muslim, yang secara serius melakukan kajian terhadap dimensi keilmuan dalam al-Qur'an, terlihat bahwa al-Qur'an melalui prinsip-prinsipnya telah mengisyaratkan pertumbuhan berbagai bidang ilmu. Di antara cabang ilmu yang memperoleh perhatian serius dan terekonstruksi secara baik oleh para ilmuwan tersebut antara lain fisika, biologi, astronomi, kimia, dan geologi. Bagi masyarakat kesenian, konsepsi al-Qur'an tentang sastra tampaknya perlu segera dirumuskan. Karena, konsepsi tersebut secara langsung maupun tidak langsung akan menjadi tawaran baru di tengahtengah pergeseran kultural sastra. 


\section{Ancangan awal sastra al-Qur'an}

Sejak awal terbentuknya, al-Qur'an memang sudah bersentuhan dengan tradisi kesusasteraan Arab yang sudah mapan, yaitu sastra Jahiliyyah. Ketika interaksi itu berlangsung dan supremasi al-Qur'an begitu dominan, maka al-Qur'an, dalam kapasitasnya sebagai dustur Islam, hadir sebagai ide sentral sekaligus solusi pemecah persoalan.

Secara sederhana interaksi yang terjadi antara al-Qur'an dan kesusasteraan berkisar pada tiga persoalan. Pertama, persoalan yang berhubungan dengan konsep estetika, hubungan antara karya sastra dan filsafat keindahan dalam ruang transenden ('aqidah). Kedua, rujukan yang mengarah pada etika (akhlaq) serta kaitannya dengan hakikat sastra dan tujuannya dalam konteks sosiologis. Ketiga, masalah perbedaan wacana dan pendekatan terhadap ekspresi dan proses kreatif dalam konteks tafsir hukum agama (syari'ah) (Salad, 2000: 32).

Dalam perspektif al-Qur'an, tujuan utama sastra adalah membangun dan menggairahkan kerinduan manusia kepada Tuhannya (dimensi spiritual) dan menyadarkan manusia atas diri dan lingkungannya (dimensi moral) (James, 1974:20). Oleh karena itu, sebagai sumber yang melengkapi setiap momentum estetika, al-Qur'an dengan tegas mensyaratkan adanya keterpaduan antara dua entitas yang berbeda dalam sebuah ruang keindahan. Entitas yang dimaksud adalah dunia nyata (realitas objektif) dan dunia yang dibayangkan (realitas imajinatif) (QS. Asy-Syura: 224).

Posisi sastrawan dalam kesusasteraan bukan sekedar alat untuk merekonstruksi kenyataan empirik, tetapi juga dituntut untuk merealisasikan kesadaran teologis yang bersifat transenden dan spiritual (Salad, 2000: 207). Pengabaian terhadap syarat yang diajukan tersebut dianggap sebagai bentuk penyelewengan, baik pada tingkat sensasi (amoralisasi estetik) maupun pada tingkat aksi (pencemaran agama dan budaya), sehingga yang bersangkutan akan mendapatkan ancaman dan sanksi (QS. Asy-Syura: 224-227).

Dalam kaitannya dengan proses kreatif, seorang sastrawan harus mampu menyatukan penalaran teologis (realitas subjektif) dan 
penalaran kultural (realitas objektif) sebagai bagian utama dari kesadaran ekspresi (realitas imajinatif). Proses kreatif terjadi pada mulanya dari seorang sastrawan yang berhadapan dengan suatu kenyataan yang ditemukan dalam masyarakatnya. Realitas itu dapat berbentuk peristiwa, norma, pandangan hidup, atau yang lain. Sastrawan merasa tidak puas terhadap realitas tersebut dan ingin memprotesnya. Sebelum protes dilakukan, dia sudah memiliki sikap, kemudian mencoba mengangankan realitas baru sebagai ganti realitas yang dia tolak. Hal inilah yang kemudian diungkapkan dalam cipta sastranya (Atmaja; 1986: 33). Oleh karenanya, unsur definitif proses kreatif berada pada sikap yang merupakan puncak kedalaman akidah (kredo) dan penghayatan seorang sastrawan terhadap agamanya. Dari sikap inilah kemungkinan nilai-nilai al-Qur'an mengada dalam diri sastrawan dan karyanya. Ini berarti, sastra menurut al-Qur'an memiliki keterikatan subordinatif terhadap agama. Karena dalam proses kreatifnya, seorang sastrawan tidak dapat melepaskan diri dari tanggung jawab yang diamanatkan Allah (QS. Al-An'am: 164, QS. AlIsra': 15). Lebih lanjut konsep sastra dalam al-Qur'an dapat ditemukan karakteristiknya sebagai ekspresi estetik yang meletakkan esensi dan fungsinya untuk menyelaraskan kehendak manusia (misi kultural) dengan kehendak ilahiyah (visi transendental).

\section{Sastra al-Qur'an dan Ideologi}

Al-Qur'an dalam menyampaikan ajarannya telah memanfaatkan kisah sebagai medianya. Kisah yang ditemukan dalam teks al-Qur'an adalah sebuah karya sastra yang memang adalah dunia imajinasi atau fiksi. Disertasi Khalafullah "al-Fan al-Qashash fi al-Qur'an al-Karim" (Seni Kisah dalam al-Qur'an Yang Mulia) yang berhasil dipertahankan di Universitas al-Azhar memperkuat pernyataan bahwa kisah dalam alQur'an adalah karya imajinatif. Meski demikian, tidak ada karya sastra yang paling imajiner mana pun yang sanggup memiliki wilayah otonomi mutlak, subjektif, dan tidak ada sangkut pautnya dengan individu atau kalangan tertentu. Setiap karya sastra lahir pada suatu 
masa dalam sejarah di suatu tempat di dunia ini juga (Heryanto, 1984: 47). Dengan kata lain, sastra al-Qur'an bukanlah produk dari dirinya sendiri, tetapi merupakan produk sejarah (Sulamini, 1981:205).

Sebagai produk sejarah, sastra al-Qur'an harus dipandang sebagai konstruksi yang kompleks dari sejumlah faktor historis-riil bahwa ia bukanlah semata-mata merefleksikan apa yang ada dalam masyarakat, tetapi lebih dari itu adalah sebuah institusi sosial yang merupakan bagian integral dari suatu masyarakat sebagaimana institusi-institusi sosial lainnya. Sebagai bagian integral, sastra al-Qur'an bukan semata dilihat sebagai produk sosial, tetapi juga memproduksi masyarakat. Sebab, ia mempunyai pengaruh normatif pada anggotaanggota masyarakat. Pada akhirnya, sastra al-Qur'an dapat dipandang sebagai suatu kekuatan sosial yang bisa mengguncang atau menggerakkan masyarakat. Ia bukan hanya merupakan representasi dari realitas, tetapi juga merupakan bagian fungsional yang diperlukan dalam kontrol sosial dan unsur penting dalam perubahan sosial (Selden, 1991:27).

Dalam sejarahnya, proses pembentukan teks sastra al-Qur'an berlangsung selama rentang waktu lebih dari 20 tahun. Selama rentang itu teks berinteraksi dengan realitas dan terbentuk oleh budaya setempat. Akan tetapi, pada fase berikutnya justru teks yang membentuk masyarakat dan merubah budaya yang ada menuju situasi yang dikehendakinya. Sebagai teks agama, aspek inilah yang menjadi karakter utamanya. Tampaknya ada hubungan dialektis yang kompleks antara sastra al-Qur'an dan sejarah, di mana hubungan itu tidak terjadi secara langsung, melainkan melalui media ideologi.

Sementara itu, ideologi itu sendiri dikenal tidak pernah berwajah tunggal. Ia selalu diwarnai kontradiksi-kontradiksi yang di dalamnya selalu ada ambisi untuk melakukan homogenisasi ekspresi dan maknamakna (Salamini, 1981:206). Di satu sisi upaya homogenisasi semacam itu bisa saja diikuti oleh kepatuhan spontan yang ditunjukkan oleh kelompok-kelompok sub-ordinat yang kepentingannya terakomodir. Tetapi, di sisi lain juga dapat memperparah kontradiksi-kontradiksi 
yang telah ada. Paling tidak hal itu disamarkan atau disembunyikan di dalam apa yang diyakini sebagai kepentingan kolektif. Jika hal itu yang terjadi dan memang demikian yang biasanya terjadi dalam sejarah, maka sesungguhnya di dalam homogenisasi terkandung potensi-potensi yang disebut emergent culture (bahaya laten) (William; 1973: 40-42).

Berdasarkan uraian tersebut dapat ditegaskan bahwa sastra alQur'an tidak akan pernah steril dari sejarah atau kondisi material yang melingkupinya. Mengingat di dalam sejarah senantiasa terjadi pertarungan-pertarungan berbagai ideologi kekuasaan, maka sastra alQur'an pun tidak lepas dari pertarungan itu. Dalam hal ini, sastra alQur'an bukan hanya mengartikulasikan ideologi yang diimposisikan, tetapi juga merespon imposisi itu sendiri sehingga terjadi pertarungan antara "kesadaran aktual" dan "kesadaran yang mungkin". Dalam konteks ini juga sastra al-Qur'an bukan hanya merupakan produk ideologi, tetapi juga sesuatu yang diperlukan oleh ideologi untuk merekonstruksi masyarakat. Dengan demikian, sastra al-Qur'an sebagai teks mungkin tampak bebas dalam hubungannya dengan apa yang dilihat sebagai realitas (ini yang disebut imajiner), tetapi ia tidak bebas dari penggunaan ideologinya.

Lebih lanjut, sastra al-Qur'an dalam merefleksikan (dan sekaligus mereproduksi) pertarungan-pertarungan dimaksud tidak berupa gambaran persis dari apa yang berlangsung dalam sejarah. Ideologi yang dominan dalam sejarah tidak dengan sendirinya juga dominan dalam teks sastra al-Qur'an. Ada semacam distorsi dari sejarah. Di sinilah sastra al-Qur'an mencoba mempertanyakan secara lebih mendasar atas semua kenyataan yang dalam beberapa hal telah diterima secara umum. Kenyataan ini seringkali membawa kegagalan bagi para penafsir dalam menelusuri unsur-unsur sejarah, melalui pendekatan sejarah, dalam sastra al-Qur'an. Dalam banyak hal sering ditemukan materi dan peristiwa yang diceritakan tidak sesuai dengan apa yang dikenal dalam sejarah. Pendekatan sejarah juga tidak dapat membantu para penafsir untuk memahami rahasia kisah-kisah alQur'an yang diulang-ulang di beberapa tempat. Oleh karena itu, sastra al-Qur'an harus dipandang sebagai sistem interpretatif. Ia hanya dapat 
dipahami jika ditempatkan dalam konteks ideologi. Karena, meminjam istilah Goenawan Mohamad (Kompas, 1986:90), sastra al-Qur'an merupakan pasemon: semacam sindiran yang sangat halus, yang menyarankan sesuatu yang bukan sebenarnya, tetapi mendekati suatu sifat tertentu. Itu berarti dalam pasemon, makna tidak secara apriori hadir. Seakan-akan makna adalah sesuatu yang hanya bisa muncul dalam suatu konteks dalam perbandingan dengan suatu keadaan, atau dengan suatu ekspresi lain yang pernah ada.

Dalam bahasa psikoanalisa hal itu dipandang sebagai sesuatu yang unconscious (tidak sadar), mampu mengatakan apa yang ingin dikatakan tetapi tidak dengan cara apa yang ingin dikatakan. Sama dengan mimpi, yang merupakan suatu degrammaticised language (bahasa yang tak bertata bahasa) atau mode of disorder (tata ketidakbertataan). Artinya, ada semacam pola-pola di dalam wacana yang kelihatan tidak berpola. Pola-pola tersebut tidak pernah (secara eksplisit) dikatakan. Sesuatu yang ingin dikatakan memang tidak dikatakan di dalam apa yang dikatakan. Persis seperti yang dikatakan Michel Foucault "the invisibility of the visible is invisible" (ketidaktampakan dari yang tampak adalah tidak tampak) (Foucotl, 1987: 24).

Yang tidak dikatakan sehingga tidak tampak itu dalam pandangan Freudian dianggap sebagai sejarah yang tertindas. Penindasan itu selalu ada. Oleh karena itu, selalu ada realitas lain di luar realitas yang hadir dalam sastra sebagai cerita. Agaknya dari sinilah Friederic Jameson memandang cerita sebagai kategori epistemologis yang esensial yang senantiasa memerlukan penafsiran (Selden, 1991: 24). Dari sini pula muncul pembenaran bahwa sastra al-Qur'an cenderung mengatakan satu hal untuk hal yang lain. Pernyataan-pernyataan yang ada di dalamnya hadir bukan untuk dirinya sendiri, tetapi lebih sebagai pendukung seluruh pandangan-dunia (world view) al-Qur'an itu sendiri.

Dalam konteks tersebut, kritik teks bertugas menemukan "kemungkinan-kemungkinan" yang tidak dikatakan oleh sastra alQur'an. Kemungkinan-kemungkinan itu antara lain berupa harapanharapan kolektif yang ada dalam suatu masyarakat pada suatu zaman. 
Dalam teks sastra, harapan-harapan itu biasanya terinferensi dalam perilaku dan ucapan para pelaku cerita. Secara kongkret, salah satu metode untuk menemukan harapan-harapan itu adalah dengan mengamati kontradiksi-kontradiksi antara apa yang dikatakan dengan situasi atau cara pengungkapan kata-kata itu. Metode tersebut ditempuh karena harapan tentang apa dan bagaimana (inilah yang dimaksud wacana ideologi) yang tersembunyi dalam sastra diartikulasikan dalam bentuk performative contradiction. Artinya, apa yang dikatakan bukan hanya berbeda, tetapi juga bertentangan dengan situasi atau cara tindakan pengungkapan kata-kata itu sendiri (Eagelton; 1991: 24).

Secara praksis, seorang kritikus teks dalam pembacaannya terhadap sastra al-Qur'an memang tidak bebas hambatan, baik hambatan tekstual maupun kultural. Apa yang dibaca, diresapi dan ditangkap dari teks itu diperhadapkan dengan nilai-nilai yang dominan dalam diri dan masyarakatnya. Jika nilai-nilai sastra al-Qur'an sama dengan nilai yang dominan, maka sastra al-Qur'an akan turut memantapkan keseluruhan tatanan masyarakat zamannya. Tetapi jika tidak, maka sastra al-Qur'an berpotensi memicu perubahan nilai dan struktur masyarakat. Dengan demikian, sekedar untuk menguatkan apa yang telah dikemukakan sebelumnya bahwa ideologi yang dominan dalam sejarah belum tentu dominan di dalam sastra al-Qur'an.

\section{Penutup}

Mengakhiri tulisan ini perlu ditegaskan kembali bahwa konsepsi al-Qur'an tentang sastra adalah cadangan pilihan-pilihan paradigmatik yang tidak wajib dipilih bagi sastra Indonesia. Dia adalah varian saja dalam rentangan sejarah sastra Indonesia. Hanya saja, wujud dari tawaran sastra al-Qur'an di sini dapat ditelusuri pada eksperimentasinya dalam hal mengaitkan seni dan penciptaan dengan kehidupan yang lebih luas. Artinya, wacana sastra al-Qur'an akan kembali mendekatkan seni dengan agama, seperti dalam tradisinya di masa lalu, di mana agama dan seni selalu rapat berkorelasi sehingga 
mampu membawakan pesan-pesan moral dan filsafat yang profetik, dan mampu pula membebaskan diri dari intervensi ideologi keduniawian yang selama dua abad terakhir telah menjadi kemerosotan seni modern.

Harus diakui, upaya menemukan paradigma pemahaman dan praktik bersastra di Indonesia tidak pernah mencapai kata akhir. Hal itu disebabkan antara lain oleh sastra Indonesia, dalam rentangan sejarahnya, lahir dari masyarakat yang terkolonisasi, sebuah masyarakat yang tumbuh dan berkembang tidak sepenuhnya dari dialektika internalnya sendiri. Kolonisasi adalah sebuah proses yang digerakkan oleh kekuatan yang berasal dari luar secara berangsur-angsur sehingga membentuk formasi sosial tertentu, posisi-posisi dan komposisi tertentu. Kiranya salah satu bentuk pembebasan sastra dari pengaruh kolonisasi tersebut adalah pengembalian sastra pada khittahnya sebagai realitas imajinatif yang mendidik dan menentramkan. Karena itu, hadirnya sastra al-Qur'an serta mengalirnya di tengah arus sastra Indonesia, mengapa tidak?. $\square$ 


\section{DAFTAR PUSTAKA}

Atmaja, Jiwa. 1986. Notasi tentang Novel dan Semiotika Sastra. Ende: Nusa Indah.

Azra, Azyumardi, dkk. 1999. Sejarah dan 'Ulum al-Qur'an.Jakarta: Pustaka Firdaus.

Darma, Budi. 1982, 1-2. Pebruari. "Moral dalam Sastra", Basis, XXX.

Eagleton, Terry. 1986. Criticism and Ideology: A Study in Marxist Literary Theory. London: Verso.

------ . Ideology: An Introduction. 1991. London: Verso.

Eddy, Nyoman Tusthi. Nukilan I: 15 Esei tentang Sastra.Flores: Nusa Indah, 1983.

Faruk H.T. 2001. Beyond Imagination: Sastra Mutakhir dan Ideologi, Yogyakarta: Gama Media.

Foucault, Michel. 1987. "Maurice Blanchot: The Thought from Outside", dalam Foucault/Blanchot, ed. Anonym. New York: Zone Books.

Heryanto, Ariel. 1984. "Sastra, Sejarah, dan Sejarah Sastra", dalam Budaya Sastra, ed. Andy Zoeltom. Jakarta: Rajawali.

James, David. 1974. Islamic Art: An Introduction. London-New York: Hamlyn.

Khalafullah, Muhammad A. Tanpa tahun. al-Qur'an Bukan Kitab Sejarah: Seni dan Sastra. Disertasi tidak diterbitkan.

Mohamad, Goenawan. 1992, 25 dan 26 Mei. "Kesusastraan, Pasemon", Kompas.

Misrawi, Zuhairi dan Anis Maftukhi. 2002. Moralitas dalam Kisah-kisah alQur'an. Jakarta: Paramadina.

Rusyana, Yus. 2000. "Memperlakukan Sastra Berbahasa Indonesia dan Sastra Berbahasa Daerah Sebagai Sastra Milik Nasional," dalam Sastra: Ideologi, Politik, dan Kekuasaan, Soediro Satoto dan Zainuddin Fananie (Ed). Surakarta: Muhammadiyah University Press. 
Salad, Hamdy. 2000. Agama Seni: Refleksi Teologis dalam Ruang Estetik. Yogyakarta: Yayasan Semesta.

Salamini, Leonardo. 1981. The Sociology of Political Praxis: An Introduction to Gramsci's Theory. London: Routledge \& Kegan Paul.

Selden, Rama. 1991. Panduan Pembaca Teori Sastra Masa Kini, terj. Rachmat Djoko Pradopo. Yogyakarta: Gadjah Mada University Press.

Williams, Raymon. 1973. Problems in Materialism and Culture: Selected Essays. London: Merlin Press. 